\title{
Polish validation of brace questionnaire
}

\author{
E Kinel $^{1 *}$, T Kotwicki $^{2}$, A Podolska $^{3}$, W Stryła ${ }^{3}$ \\ From 8th International Conference on Conservative Management of Spinal Deformities and SOSORT 2011 \\ Annual Meeting \\ Barcelona, Spain. 19-21 May 2011
}

\section{Background}

The aim of the study was to undertake the process of cultural adaptation of the Brace Questionnaire (BrQ) into Polish. The BrQ is an instrument for measuring quality of life of scoliotic adolescents who are being treated conservatively with wearing of a corrective brace [1]. The BrQ consists of 34 Likert-scale items associated with eight domains.

\section{Material and methods}

The translation from the original Greek into Polish was performed. The process of cultural adaptation of the questionnaire was compliant with the guidelines of the International Quality of Life Assessment (IQOLA) Project. It involved 30 adolescents, ages ranging between 10.0 and 17.0 years, all with Adolescent Idiopathic Scoliosis (AIS) and all wearing the same kind of brace (Chêneau). The statistical analysis calculated the reliability (internal consistency), floor and ceiling effects of the BrQ [2-5].

\section{Results}

The age was $14.0+/-1.6$ years. The adolescents were wearing the brace for more than 3 months. Cobb angle was $33.6+/-11.6$ degrees. The internal consistency was satisfactory: Cronbach's alpha coefficient was 0.82 , $\mathrm{p}<0.001$. There was no floor or celing effect.

\section{Conclusion}

Polish version of $\mathrm{BrQ}$ is reliable and can be used in Polish adolescents with idiopathic scoliosis wearing the brace to assess their quality of life.

\section{Author details}

'Department of Rehabilitation University of Medical Sciences and Rehasport Clinic Poznan, Poland. ${ }^{2}$ Spine Disorders Unit, Department of Pediatric

${ }^{1}$ Department of Rehabilitation University of Medical Sciences and Rehasport Clinic Poznan, Poland

Full list of author information is available at the end of the article
Orthopedics and Traumatology, University of Medical Sciences, Poznan, Poland. ${ }^{3}$ Department of Rehabilitation, University of Medical Sciences,

Poznan, Poland.

Published: 27 January 2012

\section{References}

1. Vasiliadis E, Grivas TB, Gkoltsiou K: Development and preliminary validation of Brace Questionnaire (BrQ): a new instrument for measuring quality of life of brace treated scoliotics. Scoliosis 2006, 1:7, doi:10.1186/ 1748-7161-1-7.

2. Beaton D, Bombardier C, Guillemin F, Ferraz M: Guidelines for the process of cross-cultural adaptation of self-report measures. Spine 2000, 15:3186-3191.

3. Asher M, Lai SM, Burton D, Manna B: The reliability and concurrent validity of Scoliosis Research Society- 22 Patient Questionnaire for Idiopathic Scoliosis. Spine 2003, 28:63-69.

4. Feise RJ, Donaldson S, Crowther ER, Menke JM, et al: Construction and validation of the Scoliosis Quality of Life Index in Adolescent Idiopathic Scoliosis. Spine 2005, 30:1310-1315.

5. Aulisa AG, Guzanti V, Perisano C, Marzetti E, et al: Determination of quality of life in adolescent with idiopathic scoliosis subjected to conservative treatment. Scoliosis 2010, 5:21, doi: 10.1186/1748-7161-5-21.

doi:10.1186/1748-7161-7-S1-O2

Cite this article as: Kinel et al:: Polish validation of brace questionnaire. Scoliosis 2012 7(Suppl 1):O2.
Submit your next manuscript to BioMed Central and take full advantage of:

- Convenient online submission

- Thorough peer review

- No space constraints or color figure charges

- Immediate publication on acceptance

- Inclusion in PubMed, CAS, Scopus and Google Scholar

- Research which is freely available for redistribution
C Biomed Central

\section{Biomed Central}

